\title{
Knowledge on complementary feeding among parents of children aged 4-12 months attending a base hospital in a rural district in Sri Lanka
}

\author{
*S N V Seram ${ }^{1}$, P M G Punchihewa ${ }^{2}$ \\ Sri Lanka Journal of Child Health, 2017; 46(2): 139-147
}

\begin{abstract}
Introduction: In developing countries, inadequate knowledge on complementary feeding $(\mathrm{CF})$ is one of the main reasons for malnutrition

Objective: To assess the knowledge on CF among parents of children aged 4 to 12 months attending a base hospital in a rural district in Sri Lanka.
\end{abstract}

Method: A descriptive cross sectional study was conducted in the paediatric ward and clinic of Base Hospital Bibile from April to June, 2016. A total of 383 parents of babies aged 4-12 months were selected by consecutive sampling. Their knowledge regarding $\mathrm{CF}$ was assessed by using a structured, pre-tested, interviewer-administered questionnaire. Questions were classified as 'must know', 'better to know' and 'good to know'.

Results: The response rate was $100 \%$. Mean total knowledge score was $33.79 \pm 4.3$ (total 49) and the distribution was positively skewed. Mean knowledge scores were $7.08 \pm 1.95$ (total 11), 9.67 \pm 1.88 (total 15), $17.03 \pm 2.08$ (total 23) in 'must know', 'better to know' and 'good to know' sections respectively. A significant correlation was only observed between age of the child and the total knowledge score $(\mathrm{p}<0.05)$. Only ethnicity $(p<0.005)$ and religion $(p<0.05)$ were significantly associated with total knowledge scores. Multiple logistic regression revealed only family income as a predictor for satisfactory knowledge among parents.

Conclusions: Parents of children aged 4 to 12 months attending Base Hospital, Bibile had satisfactory knowledge on $\mathrm{CF}$.

DOI: http://dx.doi.org/10.4038/sljch.v46i2.8270

$\overline{{ }^{1} \text { Acting Consultant Paediatrician, Base Hospital }}$ Bibile, ${ }^{2}$ Consultant Paediatrician, Lady Ridgeway Hospital for Children, Colombo

*Correspondence: viduseram@yahoo.com

(Received on 18 August 2016: Accepted after revision on 23 September 2016)

The authors declare that there are no conflicts of interest

Personal funding was used for the project.

Open Access Article published under the Creative

Commons Attribution CC-BY CC (†) License
(Keywords: Complementary feeding, knowledge, health education, infants)

\section{Introduction}

Introduction of safe and nutritious foods at about 6 months of age in addition to breastfeeding (BF) is referred to as complementary feeding $(\mathrm{CF})^{1}$. According to the World Health Organization (WHO), CF should be given timely, adequately and appropriately ${ }^{2}$. In developing countries, inadequate knowledge on CF is one of the main reasons for malnutrition ${ }^{3}$. Understanding the prevailing feeding practices of infants and young children is crucial for implementing or improving health and nutrition programmes in a country ${ }^{4}$. Some common feeding malpractices are early or delayed $\mathrm{CF}$, offering foods with unsatisfactory energy and nutrient density, giving small amounts of food with thin consistency and cultural beliefs contributing to restrict or avoid some nutritious food ${ }^{5}$. The current study was undertaken in Bibile to find out the knowledge of parents on CF as such studies have not been carried out previously in the Moneragala District.

\section{Objectives}

To assess the knowledge on CF among parents of children aged 4 to 12 months attending a base hospital in a rural district in Sri Lanka.

\section{Method}

A hospital based descriptive cross-sectional study was carried out in the paediatric ward and paediatric clinic of Base Hospital (BH), Bibile from $1^{\text {st }}$ April 2016 to 1 st July 2016, a period of 3 months. The study population comprised the parents of 4-12 month old children admitted to the paediatric ward or attended paediatric clinic in $\mathrm{BH}$, Bibile. Parents of children with known anomalies, cerebral palsy, malignant disorders or other chronic conditions, parents whose child was very sick needing emergency care, parents who failed to give consent for the study and parents whose child was on a special diet or on tube feeding were excluded.

Study sample: Consecutive sampling was done. All admissions to the paediatric ward and all who attended the paediatric clinic during the study period were included. The following formula was used to calculate the sample size ${ }^{10}: n=Z^{2} p(100$ p) $/ \mathrm{d}^{2}$ where $\mathrm{n}=$ calculated sample size, $\mathrm{Z}=\mathrm{Z}$ value corresponding to the required level of 
confidence (1.96), $\mathrm{P}=$ level of knowledge of parents on $\mathrm{CF}(50 \%)$ and $\mathrm{d}=$ required level of precision $(7.5 \%)$

$\mathrm{n}=\mathrm{Z}^{2} \mathrm{p}(100-\mathrm{p}) / \mathrm{d}^{2}$

$\mathrm{n}=1.96^{2} * 0.5 * 0.5 / 0.075^{2}$

$\mathrm{n}=171$

Design effect was taken as 2

Final sample size $=171 \times 2=342$

Data collection: A structured, pre-tested, interviewer-administered questionnaire was used. The questionnaire was translated into Sinhala and Tamil by a medical person and re-translated into English by a non-medical person. Differences between the original English version and the translated version were sorted out by discussion. Variables in questionnaire included general information of child, general information of parent, knowledge on $\mathrm{CF}$ and source of information on CF. Two bilingual health volunteers were recruited as data collectors. Principal investigator also did data collection whenever possible. Half a day training and half a day practical experience were given by the principal investigator before the study proper. They were given a brief training in research, survey procedures, and ethics, including confidentiality in research prior to data collection. Each interview took 10-15 minutes and was based on the questionnaire which the data collector filled out simultaneously. The interview was conducted in a prearranged room in $\mathrm{BH}$, Bibile at a time convenient to the parent. Only one parent was selected for the interview.

The questionnaire contained demographic and other relevant information. There were 49 questions to assess knowledge on CF. Once the interviewer completed the questionnaire, it was rechecked to determine whether all questions had been marked. The questionnaire was pretested with a sample of 25 eligible parents attending $\mathrm{BH}$, Bibile. During the pre-test, special attention was paid to understanding the questionnaire, cultural acceptability, clarity, simplicity, response rate, quality of responses, and the time taken for completion. Following the pre-test a few modifications were made to the questionnaire. Each question was worded clearly and unambiguously to ensure uniformity. Jargon was avoided and questions worded in such a way that the "respondents" could understand and respond without difficulty. Confidentially was assured both verbally and in writing. A request was made in writing to the respondents to answer the questions truthfully. Re-administration of the questionnaire was done for non-respondents. Reliability was assessed by test re-test reliability method. Leading and presuming questions were avoided.
Data analysis: Data entry was done using epi-data software. Data analysis was done using SPSS 20.0. Percentage, proportions and contingency tables were used for description of data. Association of knowledge of CF with socio-demographic characteristics was analysed using the Chi-square test. A $p$ value $<0.05$ was considered significant. Frequency distribution tables were prepared to describe knowledge on $\mathrm{CF}$ and sources of information gathered. The difference between two proportions was used for binary variables and Spearman $r$ correlation coefficient was done to assess the significance against basic sociodemographic characteristics. There were 49 questions to assess their knowledge on CF of which 11 were identified as 'must know', 15 as 'better to know' and 23 as 'good to know'. Each correct answer was given 1 and each incorrect or don't know answer 0 . Therefore, maximum possible mark was 49. Level of knowledge was categorized into four groups, 'highly satisfactory' when more than $75 \%$ knew correct answer, 'satisfactory' when $50-75 \%$ knew correct answer, 'not satisfactory' when $25-49 \%$ knew correct answer and 'highly unsatisfactory' when less than $25 \%$ knew correct answer.

Ethical issues: Ethical approval for the study was granted by the Ethics Review Committee of the Sri Lanka College of Paediatricians. Informed consent was obtained from each participating parent. They were given an opportunity to ask questions. All data collected were kept with the main investigator and used only for analysing outcome. There were no questions which disclosed any sensitive or confidential facts. This study did not involve any invasive or painful procedures. Permission to conduct the study was obtained from the Medical Superintendent, BH, Bibile and Regional Director of Health Services (RDHS), Moneragala.

\section{Results}

The study population comprised 383 parents of children aged 4-12 months, of whom 177 (46.2\%) children were male and $203(53 \%)$ were female with data missing in $3(0.8 \%)$. Whilst $160(41.8 \%)$ children were in the 4-6 month age group, 151 $(39.4 \%)$ were in the 7-9 month age group and 69 $(18 \%)$ in the $10-12$ month age group data missing in $3(0.8 \%)$. The mean age of the children was $8.01 \pm 8.429$ years.

The main caregiver to child was the mother in 378 $(98.7 \%)$ instances and the father in $04(1 \%)$ instances with data missing in $01(0.3 \%)$ instance. The monthly family income was less than 5000 Sri Lankan rupees (SLR) in $04(1 \%)$ cases, 500025,000 SLR in $260(67.9 \%)$ cases, 25,001-50,000 in $107(27.9 \%)$ cases and 50,001- 75,000 SLR in 12 (03.1) cases. Of the 383 parents, $173(45.2 \%)$ 
had one child, 155 (40.5\%) had 2 children and 54 $(14.1 \%)$ had 3 or more children with data missing in $01(0.3 \%)$ instance. Of the 383 main caregivers, 357 (93.2\%) were Sinhalese, 12 (3.1\%) were Tamil and $14(3.7 \%)$ were Muslim. Considering religion, 358 (93.5\%) were Buddhist, 11 (2.9\%) were Hindu and $14(3.7 \%)$ were Islam.

Table 1 shows the distribution of educational level of the parents in the study sample.

Table 1: Educational level of parents in sample

\begin{tabular}{|l|c|}
\hline \multicolumn{1}{|c|}{ Characteristic } & No. (\%) \\
\hline Educational level of father & $03(0.8)$ \\
No schooling & $11(02.9)$ \\
Grades 1-5 & $68(17.8)$ \\
Grade 10 $6-9$ & $214(55.9)$ \\
Grade 12 & $83(21.7)$ \\
Technical education / training school & $02(0.5)$ \\
University or higher & $01(0.3)$ \\
Data missing & $01(0.3)$ \\
\hline Educational level of mother & \\
Grades 1-5 & $05(01.3)$ \\
Grades 6-9 & $66(17.2)$ \\
Grade 10 & $238(62.1)$ \\
Grade 12 & $72(18.8)$ \\
University or higher & $01(0.3)$ \\
Data missing & $01(0.3)$ \\
\hline & $\mathbf{3 8 3}(\mathbf{1 0 0})$ \\
\hline
\end{tabular}

Fifty six percent of fathers and $62 \%$ of mothers studied up to Grade 10 . Only $0.3 \%$ in each group had a university or higher education. Nearly $1 \%$ among fathers had no schooling.

Of the 383 main caregivers, $16(4.2 \%)$ were employed and $367(95.8 \%)$ were unemployed. In $215(56.1 \%)$ instances extended family support was available at home whereas in 168 (43.9\%) instances there was no extended family support.

Table 2 shows the type of occupation of the parents in the study sample. Ninety six percent of the mothers were house wives whereas $39 \%$ of the fathers were skilled agricultural and fishery workers. There were no professionals among the mothers while only $0.5 \%$ of the fathers were professionals.

Table 2: Type of occupation of parents in sample

\begin{tabular}{|c|c|}
\hline Characteristic & No. $(\%)$ \\
\hline Occupation of mother & \\
\hline Technicians and associated & \\
\hline professionals & $03(0.8)$ \\
\hline Clerks & $03(0.8)$ \\
\hline Service workers and shop and & \\
\hline market sales workers & $02(0.5)$ \\
\hline Skilled agricultural and fishery & \\
\hline workers & $02(0.5)$ \\
\hline Craft and related trade workers & $04(1.0)$ \\
\hline Plant and machine operators and & \\
\hline assemblers & $01(0.3)$ \\
\hline Elementary occupation & $01(0.3)$ \\
\hline House wife & $367(95.8)$ \\
\hline Occupation of father & \\
\hline Professionals & $02(0.5)$ \\
\hline Technicians and associated & \\
\hline professionals & $47(12.3)$ \\
\hline Clerks & $21(05.5)$ \\
\hline Service workers and shop and & \\
\hline market sales workers & $58(15.1)$ \\
\hline Skilled agricultural and fishery & \\
\hline workers & $149(38.9)$ \\
\hline Craft and related trade workers & $25(06.5)$ \\
\hline Plant and machine operators and & \\
\hline assemblers & $40(10.4)$ \\
\hline Elementary occupation & $19(05.0)$ \\
\hline Armed forces and others & $18(04.7)$ \\
\hline Data missing & $04(01.0)$ \\
\hline Total & $383(100)$ \\
\hline
\end{tabular}

Analysis of the knowledge of main caregivers on $\mathrm{CF}$ is shown in Table 3. 
Table 3: Analysis of the knowledge of main caregivers on complementary feeding (CF) (n=383)

\begin{tabular}{|c|c|c|}
\hline Question & Correct response & $\begin{array}{l}\text { No. }(\%) \text { giving } \\
\text { correct response }\end{array}$ \\
\hline What is the recommended age to start CF? & From 6 months of age & $354(92.4)$ \\
\hline When can you introduce water to the child's diet? & 6-8 months of age & $333(86.9)$ \\
\hline When can you introduce fruits to the child's diet? & 6-8 months of age & $334(87.2)$ \\
\hline When can you introduce vegetables to child's diet? & $6-8$ months of age & $350(91.4)$ \\
\hline When can you introduce fish to the child's diet? & 6-8 months of age & $323(84.3)$ \\
\hline When can you introduce meat to the child's diet? & 6-8 months of age & $280(73.1)$ \\
\hline When can you introduce egg yolk to child's diet? & 6-8 months of age & $268(70.0)$ \\
\hline When can you introduce sugar to the child's diet? & After 1 year of age & $274(71.5)$ \\
\hline When can you introduce salt to the child's diet? & After 1 year of age & $300(78.3)$ \\
\hline $\begin{array}{l}\text { What age should a child be able to eat from the } \\
\text { usual family diet? }\end{array}$ & Around 1 year of age & $303(79.1)$ \\
\hline When should you introduce finger food to a child? & After 8 months & $300(78.3)$ \\
\hline When should a child be fed? & $\begin{array}{l}\text { All regular times of day paying } \\
\text { attention to child's hunger cues }\end{array}$ & $283(73.9)$ \\
\hline $\begin{array}{l}\text { What is the best way of feeding a child after } 9 \\
\text { months? }\end{array}$ & $\begin{array}{l}\text { Encourage self-feeding but sit } \\
\text { by and assist }\end{array}$ & $338(88.3)$ \\
\hline $\begin{array}{l}\text { How many main meals per day should be given by } 9 \\
\text { months of age? }\end{array}$ & 3 to 4 & $364(95.0)$ \\
\hline $\begin{array}{l}\text { How many snacks can be given per day by } 9 \text { months } \\
\text { of age? }\end{array}$ & 2 & $335(87.5)$ \\
\hline $\begin{array}{l}\text { Do you think that your child can be given feeds } \\
\text { after 6:00 pm if necessary? }\end{array}$ & Yes & $181(47.3)$ \\
\hline What will be the best environment to feed a child? & Together with family & $270(70.5)$ \\
\hline What is the best position to feed a child? & Seated & $353(92.2)$ \\
\hline $\begin{array}{l}\text { When your child is ill, what would you do to the } \\
\text { number of meals being offered to your child? }\end{array}$ & Increase & $114(29.8)$ \\
\hline
\end{tabular}

The responses to the question "What do you think about adding some butter / oil for your child's meal?" are shown in Table 4.

Table 4: Parent's knowledge about adding some butter/oil for child's meal (n=383)

\begin{tabular}{|l|c|c|c|}
\hline \multicolumn{1}{|c|}{ Question } & \multicolumn{2}{c|}{ Response - No. (\%) } \\
\cline { 2 - 4 } & True & False & Don't know \\
\hline Oil will help to increase calorie content & $331(86.4)$ & $08(02.1)$ & $44(11.5)$ \\
\hline $\begin{array}{l}\text { Oil will adversely affect child by increasing } \\
\text { cholesterol level }\end{array}$ & $126(32.9)$ & $144(37.9)$ & $113(29.5)$ \\
\hline Oil will help the enhance palatability & $353(92.2)$ & $08(02.1)$ & $22(05.7)$ \\
\hline Oil will help to increase weight gain of child & $361(94.3)$ & $05(01.3)$ & $17(04.4)$ \\
\hline $\begin{array}{l}\text { Oil is not recommended for infants less than } \\
\text { 9 months of age }\end{array}$ & $42(11.0)$ & $282(73.6)$ & $59(15.4)$ \\
\hline
\end{tabular}

Eighty six percent of main caregivers knew that oil will help to increase the calorie content. Thirty eight percent of main caregivers knew that oil will not adversely affect the child by increasing the cholesterol level. Ninety two percent of main caregivers knew that oil will enhance palatability and $94 \%$ knew that oil will increase weight gain of the child. Oil is recommended for infants less than 9 months of age and $73.6 \%$ main caregivers knew this fact correctly.

The responses to the question "If the child refuses to take his/her meal, what are the proper ways of persuading him/her to eat?" are shown in Table 5. 
Table 5: If child refuses to eat his/her meal, what are the proper ways of persuading him/her to eat? (n=383)

\begin{tabular}{|l|c|c|c|}
\multicolumn{2}{|c|}{ Question } & \multicolumn{3}{c|}{ Response - No. (\%) } \\
\cline { 2 - 4 } & True & False & Don't know \\
\hline Tell kindly and lovingly (data missing in 3) & $379(99.0)$ & $0(0)$ & $01(0.3)$ \\
\hline Scold (data missing in 3) & $03(0.8)$ & $376(98.2)$ & $01(0.3)$ \\
\hline Frighten/ threaten (data missing in 1) & $03(0.8)$ & $375(97.9)$ & $04(01.0)$ \\
\hline Use physical restraints \& forced feeding (data missing in 2) & $09(02.3)$ & $364(95.0)$ & $08(02.2)$ \\
\hline $\begin{array}{l}\text { Offer a variety of food with different tastes and textures } \\
\text { (data missing in 1) }\end{array}$ & $349(91.1)$ & $10(02.6)$ & $23(06.0)$ \\
\hline Tell stories during meals & $342(89.3)$ & $22(05.7)$ & $19(05.0)$ \\
\hline Allow him to watch television & $84(21.9)$ & $270(70.5)$ & $29(07.6)$ \\
\hline Take him out and show birds etc. (data missing in 1) & $358(93.5)$ & $12(03.1)$ & $12(03.1)$ \\
\hline
\end{tabular}

Ninety nine percent main caregivers knew that child should be talked to kindly and lovingly, $98 \%$ knew that scolding the child is a wrong practice, $98 \%$ knew that frightening/ threatening a child is a wrong practice and $95 \%$ knew that using physical restraint and forced feeding is wrong. Offering a variety of food with different tastes and textures is recommended to persuade the children to eat and 91\% main caregivers knew this fact. Storytelling and taking the child out and showing birds are not recommended to persuade children to eat. Only $5.7 \%$ and $3 \%$ of the main caregivers respectively knew the correct answer. Allowing children to watch TV is not recommended as a method of persuading a child to eat and $70.5 \%$ of the main caregivers knew this.

The responses to the question "What should be the consistency of food which you offer at 6,8 and 12 months of age?" are shown in Table 6 .

Ideally smooth paste is recommended at 6 months of age, smashed with pieces at 8 months of age and whole grain/pieces at 12 months of age. More than $85 \%$ of the main caregivers knew the correct answer to each question.
Table 6: What should be the consistency of food you offer at 6,8 and 12 months of age? $(n=383)$

\begin{tabular}{|l|c|}
\hline \multicolumn{1}{|c|}{ Response } & Number (\%) \\
\hline Consistency at 6 months & $49(12.8)$ \\
Liquid & $331(86.4)$ \\
Smooth paste & $02(0.5)$ \\
Thick paste & $01(0.3)$ \\
Data missing & $10(02.6)$ \\
\hline Consistency at 8 months & $42(11.0)$ \\
Smooth paste & $327(85.4)$ \\
Thick paste & $02(0.5)$ \\
Smashed with pieces & $02(0.5)$ \\
Whole grain/pieces & $01(0.3)$ \\
Data missing & $29(07.5)$ \\
\hline Consistency at 12 months & $351(91.7)$ \\
Thick paste & $02(0.5)$ \\
Smashed with pieces & \\
Whole grain/pieces & \\
Data missing & \\
\hline
\end{tabular}

The responses to the question "In case the child develops diarrhoea, what would you do with feeds?" are shown in Table 7.

Table 7: In case of the child develops diarrhoea, what would you do with feeds?

\begin{tabular}{|l|c|c|c|}
\hline \multicolumn{1}{|c|}{ Question } & \multicolumn{2}{c|}{ Response - No. (\%) } \\
\cline { 2 - 4 } & True & False & Don't know \\
\hline Avoid giving meat & $231(60.3)$ & $110(28.7)$ & $42(11.0)$ \\
\hline Avoid giving fish & $222(58.0)$ & $137(35.8)$ & $24(06.2)$ \\
\hline Avoid giving eggs (data missing in 1) & $227(59.3)$ & $132(34.5)$ & $23(06.0)$ \\
\hline Avoid giving vegetables & $01(0.3)$ & $377(98.4)$ & $03(0.8)$ \\
\hline Give usual food depending on child's appetite (data missing in 1) & $141(36.8)$ & $182(47.5)$ & $59(15.4)$ \\
\hline
\end{tabular}

The child should be given meat, fish, eggs, vegetables and usual food depending on child's appetite. Percentages of correct responses were $28.7 \%, 35.8 \%, 34.5 \%$ and $98.4 \%$ for meat, fish, eggs and vegetables respectively. Only $36.8 \%$ knew that the child should be given usual food depending on child's appetite.

The responses to the question "Once you start complementary feeds, what would you do with $B F$ ?" are shown in Table 8 . 
Table 8: Once you start complementary feeds, what would you do with breast feeding?

\begin{tabular}{|l|c|c|c|}
\hline \multicolumn{1}{|c|}{ Question } & \multicolumn{3}{c|}{ Response - No. (\%) } \\
\cline { 2 - 4 } & True & False & Don't know \\
\hline Continue with on demand breast feeding (BF) (data missing in 1) & $264(68.9)$ & $92(24.0)$ & $26(10.7)$ \\
\hline Continue with regular and frequent BF (data missing in 2) & $262(68.4)$ & $78(20.4)$ & $41(10.7)$ \\
\hline Reduce frequency of BF in daytime (data missing in 1) & $170(44.4)$ & $151(39.4)$ & $61(15.9)$ \\
\hline Refrain from BF at least for 2-3 hours before a main meal & $238(62.1)$ & $85(22.2)$ & $60(15.7)$ \\
\hline Can offer BF immediately after a main meal as substitute for water & $161(42.0)$ & $148(38.6)$ & $74(19.4)$ \\
\hline
\end{tabular}

On demand breast feeding is not recommended and only $24 \%$ of the respondents correctly answered. Regular and frequent breastfeeding should not be continued and only $20.4 \%$ of respondents answered correctly. It is recommended to reduce the frequency of breast feeding in daytime and only $44.4 \%$ of the respondents knew this fact. Refraining from breastfeeding at least for 2 to 3 hours before a main meal is recommended and
$62.1 \%$ answered correctly. Breastfeeding can be offered immediately after a main meal as a substitute for water to enhance the calorie intake and only $42 \%$ knew this fact.

The responses to the question "Why do you think it important to be knowledgeable on the proper way of introducing complementary food to your child?" are shown in Table 9.

Table 9: Why is it important to know the proper way of introducing complementary food to your child?

\begin{tabular}{|l|c|c|c|}
\hline \multicolumn{1}{|c|}{ Question } & \multicolumn{3}{c|}{ Response - No. (\%) } \\
\cline { 2 - 4 } & True & False & Don't know \\
\hline Help minimize faltering of weight with weaning (data missing in 1) & $350(91.4)$ & $07(01.8)$ & $25(06.5)$ \\
\hline Help reduce iron deficiency anaemia in children & $170(44.4)$ & $121(31.6)$ & $92(24.0)$ \\
\hline Help prevent stunting & $163(42.6)$ & $100(26.1)$ & $120(31.3)$ \\
\hline Help improve mental development (data missing in 1) & $342(89.3)$ & $22(05.7)$ & $18(04.7)$ \\
\hline
\end{tabular}

Ninety one percent knew correctly that it will help to minimize the faltering of weight with weaning. Only $44.4 \%$ of the respondents knew that it will help to reduce iron deficiency anaemia in children. Only $42.6 \%$ of the respondents correctly answered that it will help to prevent stunting. Nearly $90 \%$ of the respondents knew that knowledge on proper way of introducing complementary food is important to optimize your child's mental development and school achievements.

The responses to the question "When you are preparing complementary food, are you influenced by anyone?" are shown in Table 10 . The majority said they were not influenced.

Table 10: When you are preparing complementary food, are you influenced by anyone?

\begin{tabular}{|l|c|c|}
\multicolumn{1}{|c|}{ Question } & \multicolumn{2}{c|}{ Response - No. (\%) } \\
\cline { 2 - 3 } & Yes & No \\
\hline Are you influenced by mother (data missing in 1) & $131(34.2)$ & $251(65.5)$ \\
\hline Are you influenced by grandmother & $26(06.8)$ & $357(93.2)$ \\
\hline Are you influenced by mother-in-law (data missing in 1) & $39(10.2)$ & $343(89.5)$ \\
\hline Are you influenced by spouse & $39(01.2)$ & $344(89.8)$ \\
\hline Are you influenced by other relative (data missing in 1)) & $20(05.2)$ & $362(94.5)$ \\
\hline
\end{tabular}

The responses to the question "How do you gather information on complementary feeding?" are shown in Table 11. The most common source was the Child Health Development Record (62\%) followed by the Midwife (28.7\%). Only $1.3 \%$ of the respondents said they gather information from hospital staff.

Analysis of the level of knowledge in the study sample is shown in Table 12.
Table 11: How do you gather information on CF? $(n=383)$

\begin{tabular}{|l|c|}
\hline \multicolumn{1}{|c|}{ Response } & No. (\%) \\
\hline $\begin{array}{l}\text { From Child Health Development } \\
\text { Record }\end{array}$ & $238(62.1)$ \\
\hline From Midwife & $110(28.7)$ \\
\hline From a relative & $19(05.0)$ \\
\hline From staff members of hospital & $05(01.3)$ \\
\hline From my friends & $05(01.3)$ \\
\hline From the family physician & $03(0.8)$ \\
\hline From public media & $03(0.8)$ \\
\hline
\end{tabular}


Table 12: Analysis of level of knowledge in the study sample

\begin{tabular}{|l|c|c|c|c|}
\hline \multicolumn{1}{|c|}{ Characteristic } & $\begin{array}{c}\text { Total knowledge } \\
(\mathbf{n = 4 9 )}\end{array}$ & $\begin{array}{c}\text { 'must know' } \\
(\mathbf{n = 1 1})\end{array}$ & $\begin{array}{c}\text { 'better to know' } \\
(\mathbf{n = 1 5})\end{array}$ & $\begin{array}{c}\text { 'good to know' } \\
(\mathbf{n}=\mathbf{2 3})\end{array}$ \\
\hline Number & 383 & 383 & 383 & 383 \\
\hline Mean & 33.79 & 7.08 & 9.67 & 17.03 \\
\hline Standard error of mean & 0.21 & 0.09 & 0.09 & 0.10 \\
\hline Median & 34.0 & 7.0 & 10.0 & 17.0 \\
\hline Mode & 35.0 & 7.0 & 9.0 & 18.0 \\
\hline Standard deviation & 4.26 & 1.95 & 1.88 & 2.08 \\
\hline Minimum & 13.0 & 0.0 & 2.0 & 9.0 \\
\hline Maximum & 44.0 & 11.0 & 14.0 & 22.0 \\
\hline Percentiles 25 & 32.0 & 6.0 & 9.0 & 16.0 \\
\hline Percentiles 50 & 34.0 & 7.0 & 10.0 & 17.0 \\
\hline Percentiles 75 & 37.0 & 8.0 & 11.0 & 18.0 \\
\hline
\end{tabular}

The mean total knowledge score was $33.79 \pm 4.26$ and the distribution was positively skewed. Level of knowledge among parents was classified into 4 levels, highly satisfactory $(>75 \%)$, satisfactory $(50-$ $75 \%)$, unsatisfactory $(25-49 \%)$ and highly unsatisfactory $(<25 \%)$ depending on the mean knowledge scores in each category of questions.
Accordingly, each category showed satisfactory results. The total knowledge score was $69 \%$, 'must know' category $63 \%$, 'better to know' category $66 \%$ and 'good to know' category $73 \%$.

Correlation between knowledge scores and selected socio demographic data is shown in Table 13.

Table 13: Correlation between knowledge scores and selected socio demographic data

\begin{tabular}{|l|c|c|c|}
\hline \multicolumn{1}{|c|}{ Characteristic } & Number & Correlation coefficient & P value \\
\hline Age of child & 383 & 0.371 & $0.04 ; \mathrm{p}<0.05$ \\
\hline Number of children & 383 & -0.016 & $0.76 ; \mathrm{p}>0.05$ \\
\hline Father's age & 380 & 0.051 & $0.33 ; \mathrm{p}>0.05$ \\
\hline Mother's age & 380 & 0.052 & $0.31 ; \mathrm{p}>0.05$ \\
\hline Monthly income & 381 & 0.088 & $0.08 ; \mathrm{p}>0.05$ \\
\hline Father's education & 382 & 0.058 & $0.26 ; \mathrm{p}>0.05$ \\
\hline Mother's education & 382 & -0.025 & $0.62 ; \mathrm{p}>0.05$ \\
\hline
\end{tabular}

A significant correlation was only observed between age of the child and the total knowledge score $(\mathrm{p}<0.05)$.
Relationship between knowledge scores and selected socio demographic data is shown in Table 14.

Table 13: Relationship between knowledge scores and selected socio demographic data (n=383)

\begin{tabular}{|c|c|c|c|c|c|}
\hline Characteristic & Number & Mean & $\begin{array}{c}\text { Standard } \\
\text { deviation (SD) }\end{array}$ & $\begin{array}{c}\text { Standard error } \\
\text { of mean }\end{array}$ & *P value \\
\hline $\begin{array}{l}\text { Sex (data missing in 3) } \\
\text { Male } \\
\text { Female }\end{array}$ & $\begin{array}{l}177 \\
203\end{array}$ & $\begin{array}{l}33.84 \\
33.70\end{array}$ & $\begin{array}{l}4.32 \\
4.20\end{array}$ & $\begin{array}{l}0.325 \\
0.295\end{array}$ & $\begin{array}{l}0.623 \\
p>0.05\end{array}$ \\
\hline $\begin{array}{l}\text { Main caregiver (data missing in 1) } \\
\text { Father } \\
\text { Mother }\end{array}$ & $\begin{array}{c}04 \\
378\end{array}$ & $\begin{array}{l}31.50 \\
33.82 \\
\end{array}$ & $\begin{array}{l}2.88 \\
4.27 \\
\end{array}$ & $\begin{array}{l}1.44 \\
0.21\end{array}$ & $\begin{array}{c}0.43 \\
\mathrm{p}>0.05\end{array}$ \\
\hline $\begin{array}{l}\text { Ethnicity } \\
\text { Sinhala } \\
\text { Non Sinhalese }\end{array}$ & $\begin{array}{c}357 \\
26\end{array}$ & $\begin{array}{l}34.14 \\
29.00\end{array}$ & $\begin{array}{l}3.81 \\
6.69\end{array}$ & $\begin{array}{l}0.20 \\
1.31\end{array}$ & $\begin{array}{c}0.002 \\
\mathrm{p}<0.005\end{array}$ \\
\hline $\begin{array}{l}\text { Religion } \\
\text { Buddhists } \\
\text { Non Buddhists } \\
\end{array}$ & $\begin{array}{c}358 \\
25 \\
\end{array}$ & $\begin{array}{l}34.17 \\
28.40 \\
\end{array}$ & $\begin{array}{l}3.84 \\
6.08 \\
\end{array}$ & $\begin{array}{l}0.20 \\
1.21 \\
\end{array}$ & $\begin{array}{c}0.01 \\
\mathrm{p}<0.05\end{array}$ \\
\hline $\begin{array}{l}\text { Parents' employment status } \\
\text { Employed } \\
\text { Unemployed }\end{array}$ & $\begin{array}{c}16 \\
367\end{array}$ & $\begin{array}{l}34.68 \\
33.76\end{array}$ & $\begin{array}{l}3.43 \\
4.29\end{array}$ & $\begin{array}{l}0.85 \\
0.22\end{array}$ & $\begin{array}{c}0.23 \\
p>0.05\end{array}$ \\
\hline $\begin{array}{l}\text { Extended family support } \\
\text { Present } \\
\text { Not present }\end{array}$ & $\begin{array}{l}215 \\
168\end{array}$ & $\begin{array}{l}33.81 \\
33.77\end{array}$ & $\begin{array}{l}3.88 \\
3.77\end{array}$ & $\begin{array}{l}0.26 \\
0.36\end{array}$ & $\begin{array}{l}0.57 \\
\mathrm{p}>0.05\end{array}$ \\
\hline
\end{tabular}

*The test of significance used was the independent t-test 
Knowledge on complementary feeding among...Sri Lanka Journal of Child Health, 2017; 46(2): 139-147

Only ethnicity $(\mathrm{p}<0.005)$ and religion $(\mathrm{p}<0.05)$ were significantly associated with total knowledge scores.

\section{Multivariate analysis of correlates \\ Direct logistic regression was performed to assess the impact of 4 independent variables (age, family income, religion and ethnicity) on the likelihood that respondents would report that they had satisfactory knowledge. Two independent variables, family income $(\mathrm{p}<0.005)$ and ethnicity $(।$ $\mathrm{p}<0.05)$ were significantly correlated with satisfactory knowledge. The strongest predictor of satisfactory knowledge was the family income.}

\section{Discussion}

Most participants in the current study were Sinhalese Buddhists reflecting the ethnic and religious composition of the District. A hospital based study done in India in 2006 found that $46 \%$ of mothers had correct knowledge about recommended time for starting $\mathrm{CF}^{6}$. In our study $92 \%$ of main caregivers had correct knowledge regarding initiation of $\mathrm{CF}$. Differences between the 2 studies may be due to the well-established community midwife service and high literacy rate in Sri Lanka.

Knowledge of main caregivers was 'highly satisfactory' $(>75 \%)$ regarding the correct times to introduce water, fruit, vegetables, fish and salt to the child's diet, correct time a child should be able to eat from the usual family diet, the correct time to introduce finger food to their child, the correct consistency of food to be given to infants at 6,8 and 12 months of age, the best way of feeding a child after 9 months of age, the number of main meals and the number of snacks that should be given per day by 9 months of age and the best position to feed a child. Knowledge of main caregivers was 'satisfactory' (50-75\%) regarding the correct times to introduce meat, egg yolk and sugar to the child's diet, the correct time a child should be fed and the best environment to feed a child. Knowledge of main caregivers was 'unsatisfactory' (25-49\%) regarding giving the child feeds after 6:00 pm when necessary and increasing the number of meals being offered when the child is ill.

Only $38 \%$ of parents knew that oil will not adversely affect the child by increasing the cholesterol level. It is recommended to continue with complementary food during an illness to maintain an adequate nutrient intake, which is vital for speedy recovery ${ }^{7}$. In our study, majority of parents had poor knowledge on correct feeding practices while child is having diarrhoea. Only $37 \%$ knew that child should be given the usual food depending on the child's appetite. A previous study in Sri Lanka reported similar results ${ }^{8}$. Only $20-24 \%$ of parents were aware that 'on demand' breast feeding and regular and frequent breastfeeding should be halted once $\mathrm{CF}$ has started. Only around $40 \%$ of parents were aware that CF will help reduce iron deficiency anaemia and help prevent stunting in children.

The current study used an interviewer-administered questionnaire which greatly reduced the number of unanswered questions compared to a selfadministered questionnaire. The total knowledge score was $69 \%$, the 'must know' category $63 \%$, 'better to know' category $66 \%$ and 'good to know' category $73 \%$. A significant correlation was only observed between the age of the child and the total knowledge score $(\mathrm{p}<0.05)$. Only ethnicity $(p<0.005)$ and religion $(p<0.05)$ were significantly associated with total knowledge scores.

There is a consistently noted link between proper infant feeding and the educational level of parents ${ }^{9}$. Mother's education was found to have a significant impact on appropriate infant feeding after a comparative study involving 5 Asian countries ${ }^{10}$. The present study did not find any association between parental education level and knowledge on $\mathrm{CF}$. The present study revealed that the majority of the parents were not influenced by anyone when preparing complementary foods. The most common source of information on CF was the Child Health Development Record followed by the Midwife. This was a hospital based study and may not have represented the community as whole. It is possible to introduce recall bias in collecting information regarding feeding knowledge in retrospect. The bias is likely to be higher when a parent has more children.

\section{Conclusions}

Parents of children aged 4 to 12 months attending Base Hospital, Bibile had satisfactory knowledge on $\mathrm{CF}$.

\section{Acknowledgements}

We thank Dr. B.J.C. Perera and Professor Harendra de Silva for their guidance, the Senior House Officers, nurses and attendants for their help during data collection, Dr. M.A.A.P. Alagiyawanna, Consultant Community Physician, for help with statistical analysis and Mrs K. H. M. Anjula who assisted in numerous ways. Finally we thank all the parents who were involved with this study.

\section{References}

1. Imdad A, Yakoob MY, Bhutta ZA. Impact of maternal education about complementary feeding and provision of complementary foods on child growth in 
developing countries. BMC Public Health 2011; 11(Suppl 3): S25. https://doi.org/10.1186/1471-2458-11-S3S25

PMid:21501443 PMCid:PMC3231899

2. World Health Organisation. Report of informal meeting to review and develop indicators for complementary feeding. 3-5 December 2002 Washington DC. Available from:

http://www.who.int/nutrition/publications/ infantfeeding/a91059/en/

3. Dewey KG, Brown KH. Update on technical issues concerning complementary feeding of young children in developing countries and implications for intervention programs. Food and Nutrition Bulletin 2003. 24(1): 5-28. https://doi.org/10.1177/156482650302400 102

PMid:12664525

4. Sethi MV, Kashyap S, Seth V. Effect of nutrition education of mothers on infant feeding practices. Indian Journal of Pediatrics 2003; 70(6): 463-6.

https://doi.org/10.1007/BF02723133

PMid:12921312

5. Ijarotimi OS. Determinants of childhood malnutrition and consequences in developing countries. Current Nutrition Reports 2013; 2(3): 129-33. https://doi.org/10.1007/s13668-013-00515

6. Aggarwal A, Verma S, Faridi M. Complementary feeding-reasons for inappropriateness in timing, quantity and consistency. Indian Journal of Pediatrics 2008; 75(1): 49-53. https://doi.org/10.1007/s12098-008-00069

PMid: 18245935
7. Brown $\mathrm{KH}$, Lifschitz C. A rational approach to feeding infants and young children with acute diarrhoea. Pediatric Gastroenterology and Nutrition in Clinical Practice, 2002: p. 375-397.

8. Peiris T, Wijesinghe D. Nutritional status of under 5 year-old children and its relationship with maternal nutrition knowledge in Weeraketiya DS division of Sri Lanka. Tropical Agricultural Research 2011; 21(4): 330-9.

https://doi.org/10.4038/tar.v21i4.3309

9. Senarath U, et al. Determinants of inappropriate complementary feeding practices in young children in Sri Lanka: secondary data analysis of demographic and health survey 2006-2007. Maternal and Child Nutrition 2012; 8(s1): 60-77. https://doi.org/10.1111/j.17408709.2011.0 0375.x

PMid: 22168519

10. Bandara T, Hettiarachchi M, Liyanage C, et al. Current infant feeding practices and impact on growth in babies during the second half of infancy. Journal of Human Nutrition and Dietetics 2015; 28(4): 36674.

https://doi.org/10.1111/jhn.12253

PMid: 24976392 